\title{
Effects of pegylated interferon-related neutropenia and thrombocytopenia on treatment of chronic HBV infection
}

\author{
Bahadır Ceylan ${ }^{1 \star}$, Muzaffer Fincancı², Gülhan Eren², Cüneyt Müderrisoğlu ${ }^{3}$, Ferda Soysal ${ }^{2}$ \\ and Esra Paşaoğlu ${ }^{4}$ \\ ${ }^{1}$ Department of Infectious Diseases and Clinical Microbiology, Bezmialem Vakıf University, Turkey. \\ ${ }^{2}$ Clinics of Infectious Diseases and Clinical Microbiology, Istanbul Training and Research Hospital, Istanbul, Turkey. \\ ${ }^{3}$ Clinics of Internal Medicine, Istanbul Training and Research Hospital, Istanbul, Turkey. \\ ${ }^{4}$ Department of Pathology. Istanbul Training and Research Hospital, Istanbul, Turkey.
}

Accepted 12 September, 2012

This study was carried out to investigate the effect of neutropenia and thrombocytopenia on virologic response in cases with chronic hepatitis $B$ virus (HBV) infection receiving treatment with pegylated interferon. Patients with chronic HBV infection treated with pegylated interferon were analyzed retrospectively. Patients with or without end-of-treatment and sustained virologic response were compared in terms of basic parameters and pre-treatment, and during treatment leukocyte, neutrophil and platelet counts. Sixty-two (62) cases with chronic HBV infection (47 male; mean age was $41 \pm 10.91$ years) were included in the study. The ratio of male gender, the ratio of previous standard interferon users and the percentage of cases with a platelet count of $<100000 / \mathrm{mm}^{3}$ at the end of the $3^{\text {rd }}$ month of treatment was higher in the group with end-of-treatment virologic response compared to non-responder (male gender was $33(84.6 \%)$ and $14(60.9 \%), p=0.035$; patients with previous standard interferon use were $13(33.3 \%)$ and $2(8.7 \%), p=0.034$; and patients with thrombocytopenia were $11(28.2 \%)$ and 1 (4.3\%), $p=0.024$, respectively). Pre-treatment serum HBV DNA levels were lower in cases with end-oftreatment response compared to non-responders $(p<0.005)$. One patient $(2.6 \%)$ with end-of-treatment response and $7(30.4 \%)$ non-responders were hepatitis B virus " $e$ " antigen $(\mathrm{HBeAg})$-positive $(p=0.003)$. The only independent predictor of end-of-treatment virologic response was previous standard interferon use (odds ratio 8.157, $p=0.048$ ). There was no difference between groups with and without sustained virologic response in terms of evaluated variables. Cytopenia development during treatment did not affect pegylated interferon treatment response in our study. End-of-treatment response to treatment with pegylated interferon is enhanced in previous standard interferon users compared to treatment-naive patients.

Key words: Hepatitis B virus, thrombocytopenia, neutropenia, interferons.

\section{INTRODUCTION}

One of the current treatments of chronic hepatitis $B$ virus (HBV) infection consists of treatment with pegylated interferon (Marcellin et al., 2005; Akarca, 2010). Although

*Corresponding author. E-mail: bceylan2004@yahoo.com. Tel: +905072310236. numerous adverse effects have been reported with interferon, hematologic toxicity represents particular clinical significance (Fried, 2002). In the event of interferon-induced bone marrow suppression, reduction of dosage is recommended; however, lower doses also may reduce effectiveness of treatment (Fried, 2002). Predictors of response to treatment of chronic HBV infection with interferon have been well defined in 
literature, and it has recently been suggested that cytopenia during treatment may be one of these variables (Marcellin et al., 2005; Thomas et al., 1991; Suwantarat et al., 2010; Turbide et al., 2008; Linday et al., 2008; Alvarez-Uria et al., 2010). Although studies investigating the impact of cytopenia on response to treatment in cases with chronic hepatitis $\mathrm{C}$ virus (HCV) infection report contradictory results, the majority of these studies indicate a greater decline in neutrophil and platelet counts during the treatment in responders. The cytopenia effect of interferon and its antiviral effects are considered to be interrelated with interferon-induced changes in gene expression and therefore the smaller antiviral efficacy in cases with a less pronounced cytopenia. There exists no study evaluating the effect of the development of interferon-related cytopenia on response to treatment in cases with chronic HBV infection in the literature. The aim of this study was to investigate the impact of neutropenia and thrombocytopenia during treatment on end-of-treatment virologic response and sustained virologic response in cases with chronic hepatitis $B$ infection treated with pegylated interferon.

\section{MATERIALS AND METHODS}

The medical records of patients receiving a 12-month of treatment with pegylated interferon for chronic HBV infection in our Chronic Hepatitis Outpatient Clinic between January, 2001 and January, 2010 were retrospectively evaluated.

\section{Inclusion criteria}

All of the following criteria had to be true for inclusion in the study:

1) Hepatitis B virus surface antigen (HBsAg) positivity for at least 6 months.

2) Pre-treatment HBV DNA positivity.

3) Twelve (12) months of monotherapy with pegylated interferon treatment.

4) The presence of end-of-treatment HBV DNA measurement.

5) The presence of serum leukocyte, neutrophil and platelet counts. pre-treatment, at the end of the $3^{\text {rd }}$ month of the treatment, and endof-treatment.

\section{Exclusion criteria}

The presence of any of the following was reason for exclusion from the study:

1) Active HCV infection, HIV infection, or hepatitis D virus (HDV) infection

2) Intravenous drug abuse

3) Malignancy

4) Pregnancy

5) Liver transplantation

6) Autoimmune hepatitis

7) Hemochromatosis

8) Lack of or incompletion of 12 months of treatment with pegylated interferon

9) Lack of serum leukocyte, neutrophil and platelet counts pre- treatment, at the end of the $3^{\text {rd }}$ month of treatment, and end-oftreatment

10) Lack of end-of-treatment serum HBV DNA level measurements

\section{Variables evaluated in the study}

The variables are data pertaining to age at liver biopsy, gender, height, weight, alcohol use, Knodell score and fibrosis score at liver biopsy; previous treatment with standard interferon, total dose of previous standard interferon and the period between treatments with standard interferon and pegylated interferon; serum HBV DNA and alanine aminotransferase (ALT) levels; hepatitis B virus "e" antigen $(\mathrm{HBeAg})$ positivity; total dose of pegylated interferon administered, pre-treatment and end of $3^{\text {rd }}$ and $12^{\text {th }}$ months of treatment: blood leukocyte, neutrophil and platelet counts were recorded from patient files. Cases included in the study were allocated into two groups according to end-of-treatment and sustained virologic response, and the groups were compared in terms of variables being evaluated.

\section{Evaluation of liver histology}

Liver biopsy specimens were evaluated according to the modified Knodell scoring system.

\section{Alcohol use}

All patients declaring alcohol use were considered positive for alcohol consumption regardless of the amount or duration of use.

\section{Measurement of HBV DNA}

Pre-treatment serum HBV DNA levels were measured by bDNA (branched DNA) signal amplification (Versant HBV DNA 3.0 Assay, Bayer Corp. Diagnostics, USA, detection range 2000-100000000 copies $/ \mathrm{ml}$ ) and reverse transcription polymerase chain reaction (RTPCR) (1-Cobas TaqMan HBV test, Roche Diagnostics, France, detection range 30-110000000 IU/ml; 2-BioRad iCycler iQ system, Quiagen DNA isolation kit, Germany, detection range $20 \mathrm{IU} / \mathrm{ml}$ ).

\section{Definition of virologic response}

End-of-treatment virologic response to treatment with pegylated interferon was defined as end-of-treatment HBV DNA negativity by PCR. Sustained virologic response was defined as HBV DNA negativity by PCR 1 year after the completion of treatment with pegylated interferon.

\section{Determination of the total dose of pegylated interferon}

The total intended dose of pegylated interferon over a 12-month period was acknowledged as 1.2 units, if the patient completed the course without dose reduction. The total interferon dose of cases was calculated based on that.

\section{Calculation of the dose of previous standard interferon}

The total dose of previous treatment with standard interferon was calculated in million units, regardless of the type of standard interferon used. 
Evaluation of changes in serum leukocyte, neutrophil and platelet count during treatment

The decreases in blood leukocyte, neutrophil and platelet counts at $3^{\text {rd }}$ month and $12^{\text {th }}$ month of treatment were calculated. The number of patients with a blood leukocyte count $<3000 / \mathrm{mm}^{3}$, neutrophil count $<2500 / \mathrm{mm}^{3}$ and platelet count $<100000 / \mathrm{mm}^{3}$ at $3^{\text {rd }}$ and $12^{\text {th }}$ months of treatment were computed.

\section{Statistics}

The SPSS-17 (SPSS Inc., Chicago, IL) statistics program was used in the evaluation of data. Continuous variables without normal distribution were expressed as median and range; continuous variables with normal distribution as mean \pm standard deviation, and categorical variables as number and percentage of cases. In the comparison of patient groups with and without virologic response, the Student t-test was used for continuous variables with normal distribution, the Mann Whitney U-test for continuous variables without normal distribution, and the $x^{2}$ test for categorical variables. The logistic regression analysis was used in the multivariate comparison of the two patient groups. The two-way analysis was used in all statistical tests. A statistical significance level of $p<0.05$ was accepted.

An ethics committee approval was not obtained because of the retrospective nature of the study.

\section{RESULTS}

We evaluated 377 chronic hepatitis cases that were previously treated with pegylated interferon. Only 62 of the patients met the study criteria, 47 of them were male and 15 were female and the average age was $41 \pm$ 10.91. Peginterferon alfa-2a (180 $\mathrm{\mu g}$ subcutaneously, once weekly) was used in 42 cases (67.7\%) and peginterferon alfa-2b $(1.5 \mu \mathrm{g} / \mathrm{kg}$ subcutaneously, once weekly) was used in 20 cases (32.3\%). 15 (24.2\%) of the patients had lower doses than planned. Eight patients were $\mathrm{HBeAg}$-positive. The general characteristics of patients are shown in Table 1.

The post-treatment $\mathrm{HBeAg}$ status had been evaluated in only 5 of the $8 \mathrm{HBeAg}$-positive patients, and $3(60 \%)$ of these 5 had achieved HBeAg seroconversion. Only 1 of the 3 patients with $\mathrm{HBeAg}$ seroconversion showed endof-treatment virologic response. End-of-treatment virologic response was achieved in 39 (62.9\%) patients, while $23(37.1 \%)$ were non-responders. Comparative data between the two patient groups with and without end-of-treatment virologic response are shown in Tables 2,3 and $4.33(84.6 \%)$ of the 39 patients with virologic response to treatment, and $14(60.9 \%)$ of the 23 nonresponders were male $(p=0.035)$. Mean pre-treatment serum HBV DNA levels were $176000 \mathrm{IU} / \mathrm{ml}$ (ranges between: 230 to 110000000) in end-of-treatment responders, and $20300000 \mathrm{IU} / \mathrm{ml}$ (ranges between: 82000 to 110000000$)$ in non-responders $(p<0.005)$.

Only 1 patient $(2.6 \%)$ with end-of-treatment viral response was $\mathrm{HBeAg}$-positive, while 7 non-responders $(30.4 \%)$ demonstrated $\mathrm{HBeAg}$ positivity $(p=0.003$ ). Thirteen (13) responders (33.3\%) and 2 non-responders
$(8.7 \%)$ had received previous treatment with standard interferon $(p=0.034)$. There was no difference between the responder and non-responder groups in terms of pretreatment leukocyte, neutrophil and platelet counts or a reduction in these counts at $3^{\text {rd }}$ and $12^{\text {th }}$ months of treatment in comparison with pre-treatment levels (Table 3 ). At the end of the $3^{\text {rd }}$ month of treatment, platelet count of $<100000 / \mathrm{mm}^{3}$ was detected in $11(28.2 \%)$ responders and $1(4.3 \%)$ non-responder $(p=0.024)$.

The results of the logistic regression analysis of independent predictors of end-of-treatment virologic response are shown in Table 5. Multivariate analyses revealed only the independent variable with an impact on end-of-treatment virologic response to be previous treatment with standard interferon (Odds ratio 8.158, $\mathrm{p}=$ 0.048).

HBV DNA measurements had been performed in 57 of the total 62 patients included in the study at the end of $12^{\text {th }}$ month after completion of treatment. Of these 57 patients, $14(24.6 \%)$ had achieved sustained virologic response, while $43(75.4 \%)$ were non-responders. Mean pre-treatment HBV DNA level was 83.5 (1.84 to 110000) $(\times 1000 \mathrm{IU} / \mathrm{ml})$ in patients with sustained virologic response, and 1390 (32.5 to 100000) $(\times 1000 \mathrm{IU} / \mathrm{ml})$ in non-responders $(p=0.08)$. There was no difference between the two groups in terms of basic variables or pre-treatment blood leukocyte, platelet and neutrophil counts and changes in these counts at the $3^{\text {rd }}$ and $12^{\text {th }}$ months of treatment (Table 6) (Values relating to blood cells are not included in Table 6).

\section{DISCUSSION}

Variables such as being of Asian descent, infection during childhood, male gender, immunosuppression, HBeAg negativity, low serum ALT levels, infection with genotype D HBV, high serum HBV DNA levels and mild inflammation at liver biopsy have been indicated as predictors of poor response to interferon treatment in patients with chronic HBV infection (Marcellin et al., 2005; Thomas et al., 1991; Buster et al., 2009; Wu et al., 2009; Hansen et al., 2010; Wong and Chan, 2009; Zhong et al., 2008). In our study, although end-of-treatment response was poorer in female patients with high pretreatment serum HBV DNA levels, HBeAg positivity and no previous treatment with standard interferon, previous standard interferon use was determined as the only independent predictor of response to treatment. The discrepancies among studies investigating variables predictive of response to treatment in chronic HBV infection are due to deficiencies in our understanding of the mechanism of action of interferon in the treatment of chronic HBV infection. Besides virus-related factors such as HBV genotype, host-related factors such as differences in interferon-related gene expression are considered to have a significant impact on response to treatment (Chen et al., 2005; Taylor et al., 2007). Gene 
Table 1. General characteristics of cases included in the study.

\begin{tabular}{|c|c|}
\hline Variable & $\begin{array}{l}\text { Cases receiving pegylated interferon } \\
\text { for chronic HBV infection }(n=62)\end{array}$ \\
\hline Male gender* & $47(75.8)$ \\
\hline Age (years) $)^{\star *}$ & $41 \pm 10.91$ \\
\hline Body mass index** & $26.36 \pm 4.39$ \\
\hline Histopathologic activity index *** & $9(5-13)$ \\
\hline Fibrosis score ${ }^{* * *}$ & $1(0-4)$ \\
\hline Pre-treatment HBV DNA level $(\times 1000 \mathrm{IU} / \mathrm{ml})^{* * *}$ & $896(0.23-110000)$ \\
\hline Pre-treatment serum alanine aminotransferase level $(\mathrm{U} / \mathrm{L})^{\star * *}$ & $70(15-461)$ \\
\hline HBeAg positivity* & $8(12.9)$ \\
\hline Pegylated interferon alfa-2a/pegylated interferon alfa-2b* & $42(67.7) / 20(32.3)$ \\
\hline Alcohol use* & $14(22.6)$ \\
\hline Previous standard interferon use ${ }^{*}$ & $15(24.2)$ \\
\hline Total dose of previous standard interferon use (million units) ${ }^{* * *}$ & $271.44(162-360)$ \\
\hline $\begin{array}{l}\text { Period between the end of previous standard interferon } \\
\text { treatment and start of pegylated interferon treatment } \\
\text { (months) }\end{array}$ & $47.93(12-93)$ \\
\hline Total pegylated interferon dose $e^{\star * *}$ & $1.2(0.775-1.2)$ \\
\hline Pre-treatment blood leukocyte count $\left(/ \mathrm{mm}^{3}\right)^{\star *}$ & $7471 \pm 1799$ \\
\hline Pre-treatment blood neutrophil count $\left(/ \mathrm{mm}^{3}\right)^{\star *}$ & $4038 \pm 1192$ \\
\hline Pre-treatment blood platelet count $\left(/ \mathrm{mm}^{3}\right)^{\star \star}$ & $212806 \pm 48658$ \\
\hline
\end{tabular}

Table 2. Comparative data regarding patient groups with and without end-of-treatment virologic response to pegylated interferon.

\begin{tabular}{|c|c|c|c|}
\hline Variable & $\begin{array}{c}\text { Cases with end-of-treatment } \\
\text { virologic response; } \\
n=39(62.9 \%)\end{array}$ & $\begin{array}{c}\text { Cases without end-of-treatment } \\
\text { virologic response; } \\
n=23(37.1 \%)\end{array}$ & $\mathbf{p}$ \\
\hline Male gender* & $33(84.6)$ & $14(60.9)$ & 0.035 \\
\hline Age (years) $)^{* *}$ & $41.1 \pm 10.44$ & $40.82 \pm 11.91$ & 0.924 \\
\hline Body mass index ${ }^{* * *}$ & $26.64(18.52-32.87)$ & $25.81(18.69-47.96)$ & 0.294 \\
\hline Histopathologic activity index ${ }^{* * *}$ & $9(5-13)$ & $7(5-13)$ & 0.221 \\
\hline Fibrosis score ${ }^{* * *}$ & $1(0-4)$ & $1(0-3)$ & 0.939 \\
\hline $\begin{array}{l}\text { Pegylated interferon alfa- } \\
\text { 2a/pegylated interferon alfa-2b* }\end{array}$ & $26(66.7) / 13(33.3)$ & $16(69.6) / 7(30.4)$ & 0,814 \\
\hline $\begin{array}{l}\text { Pre-treatment HBV DNA level } \\
(\times 1000 \mathrm{IU} / \mathrm{ml})^{\star \star \star}\end{array}$ & $176(0.23-110000)$ & $20300(82-110000)$ & $<0.005$ \\
\hline $\begin{array}{l}\text { Pre-treatment serum alanine } \\
\text { aminotransferase level }(U / L)^{* \star *}\end{array}$ & $75(15-461)$ & $67(33-370)$ & 0.531 \\
\hline HBeAg positivity* & $1(2.6)$ & $7(30.4)$ & 0.003 \\
\hline Alcohol use ${ }^{*}$ & $12(30.8)$ & $2(8.7)$ & 0.061 \\
\hline Previous standard interferon use* & $13(33.3)$ & $2(8.7)$ & 0.034 \\
\hline $\begin{array}{l}\text { Total dose of previous standard } \\
\text { interferon (million units) }\end{array}$ & $324(162-360)$ & $349(338.4-360)$ & 0.121 \\
\hline
\end{tabular}


Table 2. Contd.

\begin{tabular}{|c|c|c|c|}
\hline $\begin{array}{l}\text { Period between two interferon } \\
\text { treatments (months) }\end{array}$ & $44(12-93)$ & $52(24-81)$ & 0.932 \\
\hline Total pegylated interferon dose $e^{\star \star *}$ & $1.2(0.854-1.2)$ & $1.2(0.775-1.2)$ & 0.135 \\
\hline
\end{tabular}

Table 3. Comparative data pertaining to case groups with and without end-of-treatment virologic response to pegylated interferon in terms of pre-treatment leukocyte, neutrophil and platelet counts and changes during treatment.

\begin{tabular}{|c|c|c|c|c|}
\hline Variable & & $\begin{array}{c}\text { Cases with end-of- } \\
\text { treatment virologic } \\
\text { response; } n=39 \\
(62.9 \%) \\
\end{array}$ & $\begin{array}{c}\text { Cases without end-of- } \\
\text { treatment virologic } \\
\text { response; } \\
n=23(37.1 \%) \\
\end{array}$ & $\mathbf{p}$ \\
\hline \multirow{3}{*}{ Blood leukocyte count $\left(/ \mathrm{mm}^{3}\right)$} & Pre-treatment ${ }^{\star}$ & $7598 \pm 1936$ & $7256 \pm 1557$ & 0.475 \\
\hline & $3^{\text {rd }}$ month $^{*}$ & $4388 \pm 1550$ & $4643 \pm 1440$ & 0.524 \\
\hline & $12^{\text {th }}$ month ${ }^{* *}$ & $4100(2100-11900)$ & $4000(2600-6200)$ & 0.516 \\
\hline \multirow{3}{*}{ Blood neutrophil count $\left(/ \mathrm{mm}^{3}\right)$} & Pre-treatment ${ }^{\star}$ & $4053 \pm 1310$ & $4013 \pm 987$ & 0.902 \\
\hline & $3^{\text {rd }}$ month $^{*}$ & $2096 \pm 799$ & $2278 \pm 771$ & 0.384 \\
\hline & $12^{\text {th }}$ month $^{\star *}$ & $2100(1100-3700)$ & $2000(1200-6099)$ & 0.610 \\
\hline \multirow{3}{*}{$\begin{array}{l}\text { Blood thrombocyte count } \\
\left(\times 1000 / \mathrm{mm}^{3}\right)\end{array}$} & Pre-treatment ${ }^{\star *}$ & $199(123-383)$ & $227(132-309)$ & 0.055 \\
\hline & $3^{\text {rd }}$ month $^{*}$ & $134 \pm 46$ & $147 \pm 36$ & 0.228 \\
\hline & $12^{\text {th }}$ month $^{* *}$ & $128(63-267)$ & $139(68-210)$ & 0.489 \\
\hline \multirow{2}{*}{$\begin{array}{l}\text { Decrease in leukocyte versus } \\
\text { pre-treatment count }\left(/ \mathrm{mm}^{3}\right)\end{array}$} & $3^{\text {rd }}$ month $^{*}$ & $3209 \pm 1560$ & $2613 \pm 1491$ & 0.145 \\
\hline & $12^{\text {th }}$ month $^{*}$ & $3337 \pm 1769$ & $2887 \pm 1300$ & 0.293 \\
\hline \multirow{2}{*}{$\begin{array}{l}\% \text { decrease in leukocyte count } \\
\text { versus pre-treatment }\end{array}$} & $3^{\text {rd }}$ month $^{\star \star}$ & $42.59[(-9.43)-71.43]$ & $39.47[(-26.92)-60.76]$ & 0.149 \\
\hline & $12^{\text {th }}$ month $^{* *}$ & $47.22[(-1.47)-68.37]$ & $41.3[(-0.02)-58.38])$ & 0.229 \\
\hline \multirow{2}{*}{$\begin{array}{l}\text { Decrease in neutrophil versus } \\
\text { pre-treatment count }\left(/ \mathrm{mm}^{3}\right)\end{array}$} & $3^{\text {rd }}$ month $^{\star *}$ & $1800[(-1100)-4900]$ & $2000[(-2100)-3100]$ & 0.948 \\
\hline & $12^{\text {th }}$ month ${ }^{\star *}$ & $2000[(-400)-6000]$ & $1900[(-3999)-3400]$ & 0.873 \\
\hline \multirow{2}{*}{$\begin{array}{l}\% \text { decrease in neutrophil count } \\
\text { versus pre-treatment }\end{array}$} & $3^{\text {rd }}$ month $^{* *}$ & $47.36[(-35.48)-81.82]$ & $48.57[(-116.67)-70.45]$ & 0.771 \\
\hline & $12^{\text {th }}$ month $^{*}$ & $43.47 \pm 22.22$ & $33.48 \pm 54.06$ & 0.311 \\
\hline \multirow{2}{*}{$\begin{array}{l}\text { Decrease in platelet count } \\
\text { versus pre-treatment count } \\
\left(\times 1000 / \mathrm{mm}^{3}\right)\end{array}$} & $3^{\text {rd }}$ month $^{\star *}$ & $75[(-88)-259]$ & $78[(-9)-170]$ & 0.821 \\
\hline & $12^{\text {th }}$ month ${ }^{\star *}$ & $73(10-176)$ & $83[(-3)-142]$ & 0.091 \\
\hline \multirow{2}{*}{$\begin{array}{l}\% \text { decrease in platelet count } \\
\text { versus pre-treatment }\end{array}$} & $3^{\text {rd }}$ month $^{* *}$ & $34.08[(-41.71)-67.62]$ & $36[(-6.82)-58.49]$ & 0.471 \\
\hline & $12^{\text {th }}$ month $^{* *}$ & $32.8(4.74-72.06)$ & $37.77[(-2.21)-52.2]$ & 0.250 \\
\hline
\end{tabular}

expression studies have demonstrated apparent distinctions between patients with chronic HCV infection with and without sustained response to treatment in terms of genes with increased or decreased expression with interferon (Chen et al., 2005; Taylor et al., 2007). We attribute discrepancies between various studies to the 
Table 4. Comparative data pertaining to case groups with and without end-of-treatment virologic response to pegylated interferon in terms of changes in leukocyte, neutrophil and platelet counts during treatment.

\begin{tabular}{|c|c|c|c|}
\hline Variable & $\begin{array}{c}\text { Cases with end-of-treatment } \\
\text { virologic response; } \\
n=39(62.9 \%)\end{array}$ & $\begin{array}{c}\text { Cases without end-of } \\
\text { treatment virologic response; } \\
n=23(37.1 \%)\end{array}$ & $p$ \\
\hline $\begin{array}{l}\text { Cases with blood leukocyte }<3.000 / \mathrm{mm}^{3} \\
\text { at } 3^{\text {rd }} \text { month of treatment, } \mathrm{n}(\%)\end{array}$ & $6(15.4)$ & $3(13)$ & 1.000 \\
\hline $\begin{array}{l}\text { Cases with blood leukocyte }<3.000 / \mathrm{mm}^{3} \\
\text { at } 12^{\text {th }} \text { month of treatment, } \mathrm{n}(\%)\end{array}$ & $7(17.9)$ & $3(13)$ & 0.731 \\
\hline $\begin{array}{l}\text { Cases with blood neutrophil }<1.500 / \mathrm{mm}^{3} \\
\text { at } 3^{\text {rd }} \text { month of treatment, } \mathrm{n}(\%)\end{array}$ & $11(28.2)$ & $4(17.4)$ & 0.378 \\
\hline $\begin{array}{l}\text { Cases with blood neutrophil }<1.500 / \mathrm{mm}^{3} \\
\text { at } 12^{\text {th }} \text { month of treatment, } \mathrm{n}(\%)\end{array}$ & $12(30.8)$ & $3(13)$ & 0.138 \\
\hline $\begin{array}{l}\text { Cases with blood platelet }<100.000 / \mathrm{mm}^{3} \\
\text { at } 3^{\text {rd }} \text { month of treatment, } \mathrm{n}(\%)\end{array}$ & 11 (28.2) & $1(4.3)$ & 0.024 \\
\hline $\begin{array}{l}\text { Cases with blood platelet }<100.000 / \mathrm{mm}^{3} \\
\text { at } 12^{\text {th }} \text { month of treatment, } \mathrm{n}(\%)\end{array}$ & $9(23.1)$ & $3(13)$ & 0.508 \\
\hline
\end{tabular}

Table 5. Results of logistic regression analysis evaluating independent predictors of end-of-treatment virologic response.

\begin{tabular}{lccc}
\hline Variable & Beta value & Odds ratio & p-value \\
\hline Gender & 1.315 & 3.724 & 0.119 \\
Pre-treatment serum HBV DNA level & 0 & 1 & 0.128 \\
HBeAg status & -0.639 & 0.528 & 0.673 \\
Previous standard interferon use & 2.099 & 8.157 & 0.048 \\
& & & \\
$\begin{array}{l}\text { Platelet count }<100.000 / \mathrm{mm}^{3} \text { at } 3^{\text {rd }} \\
\text { month of treatment }\end{array}$ & -1.649 & 0.192 & 0.161 \\
\hline
\end{tabular}

failure of including interferon-responsive genes among variables that have an impact on response to treatment. The systemic effects of interferon such as cytopenia, depression and loss of weight, and its antiviral affects are considered to be interrelated with interferon-induced changes in gene expression (5 to 8 ). We aimed to incorporate genetic factors, the most important hostrelated factor, as a variable influencing response to treatment by including cytopenia, a systemic effect of interferon, among the variables investigated. We encountered four previous studies investigating the effect of interferon-related cytopenia on response to treatment in chronic HCV infection, but none conducted in the chronic HBV infection setting (Suwantarat et al., 2010; Turbide et al., 2008; Linday et al., 2008; Alvarez-Uria et al., 2010). Our study is the first in this regard. A study on 111 patients with chronic HCV infection receiving 48 weeks treatment with standard interferon plus ribavirin demonstrated a greater decline in blood leukocyte count during the $2^{\text {nd }}$ week of treatment and in blood neutrophil count during the $2^{\text {nd }}$ and $4^{\text {th }}$ weeks of treatment in the patient group who did not achieve sustained virologic response (Turbide et al., 2008). There was no difference between patient groups in terms of platelet count during treatment. It has been suggested that in patients with chronic HCV infection, neutrophils comprise the location of conservation and replication for HCV, that patients with a high HCV RNA load within neutrophils demonstrate a greater decline in neutrophil count with interferon treatment, and that the high HCV RNA load causes poorer response to treatment. As opposed to the early phase $\left(2^{\text {nd }}\right.$ and $4^{\text {th }}$ weeks) of treatment in this study, we evaluated neutrophil and leukocyte counts in later phases $\left(3^{\text {rd }}\right.$ and $12^{\text {th }}$ months) of treatment. Even if statistically insignificant, the drop in neutrophil counts at the $3^{\text {rd }}$ month of treatment was less pronounced in patients with sustained virologic response compared to nonresponders. 
Table 6. Comparative data pertaining to case groups with and without sustained virologic response to pegylated interferon.

\begin{tabular}{|c|c|c|c|}
\hline Variable & $\begin{array}{l}\text { Cases with sustained virologic } \\
\text { response; } n=14(24.6 \%)\end{array}$ & $\begin{array}{l}\text { Cases without sustained virologic } \\
\text { response; } n=43(75.4 \%)\end{array}$ & p \\
\hline Male gender* & $12(85.7)$ & $31(72.1)$ & 0.478 \\
\hline Age $(\text { years })^{\star *}$ & $46(34-59)$ & $40(31-61)$ & 0.846 \\
\hline Body mass index** & $25.95(22.95-28.69)$ & $26.45(21.97-30.48)$ & 0.934 \\
\hline Histopathologic activity index ** & $9.5(7-13)$ & $9(5-12)$ & 0.880 \\
\hline Fibrosis score ${ }^{\star *}$ & $2(1-4)$ & $1(0-3)$ & 0.680 \\
\hline Pre-treatment HBV DNA level $(\times 1000 \mathrm{IU} / \mathrm{ml})^{\star *}$ & $83.5(1.84-110000)$ & $1390(32.5-100000)$ & 0.080 \\
\hline $\begin{array}{l}\text { Pre-treatment serum alanine } \\
\text { aminotransferase level }(U / L)^{* *}\end{array}$ & $56(15-71)$ & $75(48-337)$ & 0.993 \\
\hline HBeAg positivity* & $0(0)$ & $7(16.3)$ & 0.176 \\
\hline Alcohol use* & $4(28.6)$ & $8(18.6)$ & 0.463 \\
\hline $\begin{array}{l}\text { Pegylated interferon alfa-2a/pegylated } \\
\text { interferon alfa- } 2 b^{*}\end{array}$ & $8(57.1) / 6(42.9)$ & $30(69.8) / 13(30.2)$ & 0.384 \\
\hline Previous standard interferon use ${ }^{*}$ & $6(42.9)$ & $9(20.9)$ & 0.106 \\
\hline $\begin{array}{l}\text { Total dose of previous standard interferon } \\
\text { (million units) }\end{array}$ & $252(162-360)$ & $338.4(162-360)$ & 0.510 \\
\hline $\begin{array}{l}\text { Period between two interferon treatments } \\
(\text { months })^{\star *}\end{array}$ & $39(12-93)$ & $44(12-84)$ & 0.636 \\
\hline Total dose of pegylated interferon ** & $1.2(1.1-1.2)$ & $1.15(0.854-1.2)$ & 0.200 \\
\hline
\end{tabular}

*: count $(\%)$.

$* *$ : median (range).

It has been suggested that in patients with chronic HCV infection undergoing treatment with pegylated interferon and ribavirin, a decline in blood leukocyte, neutrophil and platelet counts indicate better response to treatment (Suwantarat et al., 2010; Linday et al., 2008; Alvarez-Uria et al., 2010). Although we did not find any difference in neutrophil and leukocyte counts during treatment, a serum platelet count of $<100000 / \mathrm{mm}^{3}$ in 3 months of treatment was more common in the patient group with end-of-treatment virologic response compared with nonresponders, albeit without significance in the multivariate analysis. We attribute this to the small number of patients included in our study.

We found previous standard interferon use to be correlated with an increased end-of-treatment virologic response to pegylated interferon. Previous studies have reported 18.4 to $36.9 \%$ end-of-treatment or posttreatment virologic response with a second course of standard interferon following relapse or non-response with previous standard interferon treatment (Manesis et al., 2001; Ruiz-Moreno, 1995; Liu et al., 2007). In a study conducted on non-responders to the first course of treatment with standard interferon that were treated with pegylated interferon and monitored for 26 weeks following treatment, virologic response was $35 \%$ at the end of the follow-up period (Flink et al., 2006). Similarly, we found end-of-treatment virologic response was 33.3\% with pegylated interferon treatment in patients who received previous therapy with standard interferon. We considered the better treatment response was with pegylated interferon treatment in the presence of previous use of standard interferon to the continuing effects of interferon. The previously reported ongoing beneficial effects of interferon in chronic HBV infection during the follow-up period have been justified with the following theories:

1) The diminishing antiviral T-cell response to wild type HBV by mutant T-cell epitopes in the precore/core region and the amendment of $\mathrm{T}$-cell response to the virus due to the reduction of these mutants by interferon (Marinos et al., 1996).

2) The impairment of T-cell response due to high serum HBV DNA levels and the reduction in HBV DNA levels by interferon resulting in enhanced T-cell activity (Chisari et al., 1995; Bertoletti et al., 1994).

3) The stimulation of virus-specific response by the immunomodulatory effect of interferon (Papatheodoridis et al., 2001; van Zonneveld et al., 2004).

Regarding the post-treatment effects of interferon; 
despite a lack of difference between interferon and placebo or lamivudine usage in terms of end-of-treatment virologic response, pegylated interferon gave better results in the long-term follow-up after treatment (Carreno et al., 1999; Marcellin et al., 2009; Lın et al., 1999). Furthermore, in support of the long-term effects of interferon treatment, biochemical response and $\mathrm{HBeAg}$ seroconversion were improved at 24 weeks after completion of interferon treatment compared to end-oftreatment results (Caruntu et al., 2009). However, the long-term effects of interferon are controversial due to studies reporting no difference with or without interferon treatment in terms of virologic response during long-term follow-up (Truong et al., 2005; Hsu et al., 2008).

Previous studies have indicated that relapses generally occur during the first year following treatment with pegylated interferon, and thus, we selected the end of the first year post-treatment for the evaluation of sustained virologic response (Brunetto et al., 2003). We found pretreatment HBV DNA levels to be lower, though not with statistical significance, in responders compared with nonresponders at the end of the first year following treatment. We attribute the lack of any difference between responders and non-responders at the end of the first year post-treatment in terms of variables with an established impact on response to treatment to the insufficient number of patients evaluated.

The results of this study indicate that a declining platelet or neutrophil count during treatment with pegylated interferon has no impact on response to treatment in cases with chronic HBV infection, and endof-treatment response to treatment with pegylated interferon is enhanced in previous standard interferon users compared to treatment-naive patients.

\section{REFERENCES}

Akarca US (2010). Treatment of chronic hepatitis B. Türkiye Klinikleri J Gastroenterohepatol-Special Topics 3 (1):53-63.

Alvarez-Uria G, Day JN, Nasir AJ, Russell SK, Vilar FJ (2010). Reduction in neutrophil count during hepatitis C treatment: Drug toxicity or predictor of good response? Dig. Dis. Sci. 55(7):20582062.

Bertoletti A, Costanzo A, Chisari FV, Levrero M, Artini M, Sette A, Penna A, Giuberti T, Fiaccadori F, Ferrari C (1994). Cytotoxic T lymphocyte response to a wild type hepatitis $B$ virus epitope in patients chronically infected by variant viruses carrying substitutions within the epitope. J. Exp. Med. 180(3):933-943.

Brunetto MR, Oliveri F, Colombatto P, Coco B, Ciccorossi P, Bonino F (2003). Treatment of $\mathrm{HBeAg-negative} \mathrm{chronic} \mathrm{hepatitis} \mathrm{B} \mathrm{with}$ interferon or pegylated interferon. J. Hepatol. 39(1):164-167.

Buster E, Hansen BE, Lau G, Pıratvisuth T, Zeuzem S, Steyerberg EW, Janssen $H$ (2009). Factors that predict response of patients with hepatitis $B$ e antigen-positive chronic hepatitis $B$ to peginterferon-alfa. Gastroenterol. 137(6):2002-2009.

Carreno V, Marcellin P, Hadziyannis S, Salmeron J, Diago M, Kıtıs GE, Vafiadis I, Schalm SW, Zahm F, Manzarbeitia F, Jiménez FJ, Quiroga JA (1999). Retreatment of chronic hepatitis B e antigenpositive patients with recombinant interferon alfa-2a. Hepatol. 30(1):277-282.

Caruntu FA, Streinu-Cercel A, Gheorghe LS, Grigorescu M, Sporea I, Stanciu C, Andronescu D, Voinea F, Diculescu M, Oproiu A, Voiosu
$R$ (2009). Efficacy and safety of peginterferon alfa-2a (40KD) in HBeAg-positive chronic hepatitis B patients. J. Gastrointestin Liver Dis. 18(4):425-431.

Chen L, Borozan I, Feld J, Sun J, Tannis LL, Coltescu C, Heathcote J, Edwards AM, McGilvray ID (2005). Hepatic gene expression discriminates responders and nonresponders in treatment of chronic hepatitis C viral infection. Gastroenterol. 128(5):1437-1444.

Chisari FV, Ferrari C (1995). Hepatitis B virus immunopathogenesis. Annual Rev. Immunol. 13:29-60.

Flink HJ, Hansen BE, Heathcote EJ, Feinman SV, Simsek H, Karayalcin $S$, Mach T, Leemans WF, de Man RA, Verhey E, Schalm SW, Janssen HL; HBV 99-01 Study Group (2006). Succesful treatment with peginterferon alfa-2b of $\mathrm{HBeAg}$-positive $\mathrm{HBV}$ non-responders to standard interferon or lamiudine. Am. J. Gastroenterol. 101(11):25239.

Fried MW (2002). Side effects of therapy of hepatitis C and their management. Hepatol. 36(5):237-244.

Hansen BE, Buster EH, Steyerberg EW, Lesaffre E, Janssen HL (2010). Prediction of the response to peg-interferon-alfa in patients with HBeAg positive chronic hepatitis B using decline of HBV DNA during treatment. J. Med. Virol. 82(7):1135-1142.

Hsu HY, Tsai HY, Wu TC, Chiang CL, Ni YH, Chen PJ, Chang MH (2008). Interferon-alpha treatment in children and young adults with chronic hepatitis B: a long-term follow-up study in Taiwan. Liver Int. 28(9):1288-1297.

Lın SM, Sheen IS, Chien RN, Chu CM, Liaw YF (1999). Long-term beneficial effect of interferon therapy in patients with chronic hepatitis B virus infection. Hepatol. 29(3):971-975.

Linday KL, Morishima C, Wright EC, Dienstag JL, Shiffman ML, Everson GT, Lok AS, Bonkovsky HL, Lee WM, Morgan TR, Ghany MG (2008). Blunted cytopenia and weight loss: New correlates of virologic null response to re-treatment of chronic hepatitis C. Clin. Gastroenterol. Hepatol. 6(2):234-241.

Liu DL, Luo KX, Feng XR, Fuo QX, Hou JL (2007). Study of the relapse of patients with chronic hepatitis $B$ undergoing first and repeated recombinant interferon-alpha therapy during long-term follow-up. Zhonghua Yi Xue Za Zhi, 87(26):1840-1843.

Manesis EK, Hadziyannis SJ (2001). Interferon alpha treatment and retreatment of hepatitis B Eantigen-negative chronic hepatitis B. Gastroenterol. 121(1):101-109.

Marcellin P, Asselah T, Boyer N (2005). Treatment of chronic hepatitis B. In: Thomas HC, Lemon S, Zuckerman AJ (eds). Viral Hepatitis. Blackwell Publishing Ltd., Massachusetts, A.B.D. pp.323-336.

Marcellin P, Bonino F, Lau GK, Farci P, Yurdaydın C, Pıratvisuth T, Jin R, Gurel S, Lu ZM, Wu J, Popescu M, Hadziyannis S; Peginterferon alfa-2a in HBeAg-negative Chronic Hepatitis B Study Group (2009). Sustained response of hepatitis $B$ e antigen-negative patients 3 years after treatment with peginterferon alfa-2a. Gastroenterol. 136(7):2169-2179.

Marinos G, Naoumov NV, Williams R (1996). Impact of complete inhibition of viral replication on the cellular immune response in chronic hepatitis B virus infection. Hepatol. 24(5):991-995.

Papatheodoridis GV, Manesis E, Hadziyannis SJ (2001). The long-term outcome of interferon-alpha treated and untreated patients with HBeAg-negative chronic hepatitis B. J. Hepatol. 34(2):306-313.

Ruiz-Moreno M (1995). Interferon treatment in children with chronic hepatitis B. J Hepatol. 22(1):49-51.

Suwantarat N, Tice AD, Khawcharoenporn T, Chow DC (2010). Weight loss, leukopenia and thrombocytopenia associated with sustained virologic response to hepatitis C treatment. Int. J. Med. Sci. 7(1):3642.

Taylor MW, Tsukahara T, Brodsky L, Schaley J, Sanda J, Stephens MJ, McClintick JN, Edenberg HJ, Li L, Tavis JE, Howell C, Belle SH (2007). Changes in gene expression during pegylated interferon and ribavirin therapy of chronic hepatitis $C$ virus distinguish responders from nonresponders to antiviral therapy. J. Virol. 81(7):3391-3401.

Thomas HC, Karayiannis P, Brook G (1991). Treatment of hepatitis Bvirus infection with interferon. Factors predicting response to interferon. J. Hepatol. 13(1):4-7.

Truong BX, Seo Y, Kato M, Hamano K, Ninomiya T, Katayama M, Kato H, Yano Y, Hayashi Y, Kasuga M (2005). Long-term follow-up of Japanese patients with chronic hepatitis $B$ treated with interferon- 
alpha. Int. J. Mol. Med. 16(2):279-284.

Turbide C, Soulellis CA, Deschenes M, Hilzenrat N (2008). Does a rapid decline in the hematological and biochemical parameters induced by interferon and ribavirin combination therapy for the hepatitis $C$ virus predict a sustained viral response. Can. J. Gastroenterol 22(2):149152.

van Zonneveld M, Honkoop P, Hansen BE, Niesters HG, Darwish MS, deMan RA, Schalm SW, Janssen HL (2004). Long-term follow-up of alpha-interferon treatment of patients with chronic hepatitis B. Hepatol. 39(3):804-810.

Wong GL, Chan HL (2009). Predictors of treatment response in chronic hepatitis B. Drugs 69(16):2167-2177.
Wu XJ, Wang Y, Chen J, Wang GQ (2009). Baseline predictors of virological response for chronic hepatitis B patients. World J. Gastroenterol. 15(34):4311-4315.

Zhong RX, Lai CY, Liang D, Long H (2008). Responses of peginterferon-alpha $2 \mathrm{a}$ antiviral therapy in chronic hepatitis $\mathrm{B}$ patients. Zhonghua Gan Zang Bing Za Zhi 16(4):279-282. 